Check for updates

Cite this: RSC Adv., 2019, 9, 287

Received 22nd October 2018

Accepted 11th December 2018

DOI: $10.1039 / \mathrm{c} 8 \mathrm{ra08739c}$

rsc.li/rsc-advances

\section{Experimental and theoretical investigation of cyclometallated platinum(II) complex containing adamantanemethylcyanamide and 1,4- naphthoquinone derivative as ligands: synthesis, characterization, interacting with guanine and cytotoxic activity $\uparrow$}

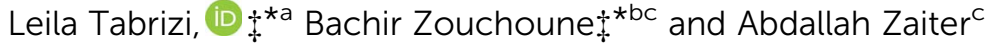

A new cyclometallated platinum(॥) complex with 1-adamantanemethylcyanamide (1-ADpcydH) and 2[amino(2-phenylpyridine)]-1,4-naphthoquinone (1,4-NQ) ligands with the formula cis-Pt(1,4-NQ)(1ADpcyd) $\left(\mathrm{H}_{2} \mathrm{O}\right)$ was synthesized and fully characterized. Cellular uptake, DNA platination, and cytotoxicity against human MCF-7 breast, HepG-2 liver hepatocellular carcinoma, and HT-29 colon cancer cell lines were evaluated. The interaction of guanine $(\mathrm{G})$ with cis-Pt(1,4-NQ)(1-ADpcyd) $\left(\mathrm{H}_{2} \mathrm{O}\right)$ was studied by ${ }^{195} \mathrm{Pt}$ NMR and mass spectroscopy. Furthermore, DFT calculations were performed on the complexes cis$\mathrm{Pt}(1,4-\mathrm{NQ})(1-\mathrm{ADpcyd})\left(\mathrm{H}_{2} \mathrm{O}\right) \quad 1$ and cis-Pt(1,4-NQ)(1-ADpcyd)(G) 2 using the BP86-D and B3LYP functionals, in order to gain deeper insights into the molecular and electronic structures. Decomposition energy analysis gave a clear understanding of the bonding within both complexes, showing that the interactions were governed by two-third ionic and one-third covalent characters, which were stronger between the guanine and the $\mathrm{Pt}(॥)$ center than those between water and the $\mathrm{Pt}(॥)$.
\end{abstract}

\section{Introduction}

Recently, cyclometallated platinum complexes containing $\mathrm{N}$ donor ligands have been the object of much research attention due to interest in their biological activities. ${ }^{1-9}$ The antitumor activity of different platinum(II) complexes is associated with the platination of DNA, generally through binding to guanine. Hence, anticancer platinum(II) complexes have been investigated with guanine derivatives in theoretical and experimental studies and they have shown a high selectivity for binding to N7 of guanine. ${ }^{\mathbf{1 0 - 2 2}}$

1,4-Naphthoquinone and its derivatives are attracting great attention as they show important properties that would be useful in many biological processes. ${ }^{23-27}$ Recently,

${ }^{a}$ School of Chemistry, National University of Ireland Galway, University Road, Galway, Ireland, H91 TK33.E-mail: LEILA.TABRIZI@nuigalway.ie

${ }^{b}$ Laboratoire de Chimie appliquée et Technologie des Matériaux, Université Larbi Ben M'Hidi - Oum El Bouaghi, 04000 Oum El Bouaghi, Algeria. E-mail: bzouchoune@ gmail.com

'Unité de Recherche de Chimie de l'Environnement et Moléculaire Structurale, Université Constantine (Mentouri), 25000 Constantine, Algeria

$\dagger$ Electronic supplementary information (ESI) available: ${ }^{1} \mathrm{H},{ }^{13} \mathrm{C}$ NMR spectra of free ligands and ${ }^{1} \mathrm{H},{ }^{13} \mathrm{C},{ }^{195} \mathrm{Pt}$ NMR spectra of $\mathrm{Pt}(\mathrm{II})$ complex and mass spectra of ligand free ligands and Pt(II) complex. See DOI: 10.1039/c8ra08739c

\$ These authors contributed equally.
naphthoquinone-platinum(II) complexes were studied as anticancer drugs and showed significant biological activity and DNA-binding as a result of coordination of the quinone to $\operatorname{Pt}\left(\right.$ II). ${ }^{28}$

Adamantane derivatives are usually regarded as a 'lipophilic bullet' for improving the lipophilicity in biological activities with potential anticancer activity. ${ }^{29-35}$ Recently, we focused attention on the development of $\mathrm{Ni}$ (II), $\mathrm{Co}$ (II), $\mathrm{Ru}$ (II), Ir(III), $\mathrm{Pt}$ (II), Pd(II), and triorganotin(Iv) complexes containing phenylcyanamide derivatives as monodentate ligands with biological properties. ${ }^{36-43}$ Specifically, we synthesized and used 1-adamantanemethylcyanamide (1-ADpcydH) as a monodentate ligand for a platinum(II) complex.

We here report the synthesis and characterization of a new cyclometallated platinum(II) complex of 1-adamantanemethylcyanamide (1-ADpcydH) and 2-[amino(2phenylpyridine)]-1,4-naphthoquinone (1,4-NQ) ligands with the formula cis-Pt(1,4-NQ)(1-ADpcyd) $\left(\mathrm{H}_{2} \mathrm{O}\right)$. The cellular uptake, DNA platination, and cytotoxicity against human MCF-7 breast, HepG-2 liver hepatocellular carcinoma, and HT-29 colon cancer cell lines were evaluated. Moreover, this complex was studied by theoretical calculations and in an experimental evaluation for its interaction with guanine. The theoretical study was performed on both complexes cis-Pt(1,4-NQ)(1-ADpcyd) $\left(\mathrm{H}_{2} \mathrm{O}\right), \mathbf{1}$, and cis-Pt(1,4-NQ)(1-ADpcyd)(G), 2, in order to obtain 
information about their molecular structures by analyzing their molecular orbitals, electronic structures, natural charges, Wiberg bond indices (WBI), and interaction energies using the BP86-D and B3LYP methods, ${ }^{44-52}$ which have proved their reliability for metallic complexes in many previous studies. We endeavor herein to compare our results with those available experimentally in the literature of related systems.

\section{Experimental}

\subsection{Materials and methods}

All reagents and solvents were commercially available and used without further purification. The 1-adamantanemethylcyanamide (1-ADpcydH) ligand was synthesized as previously reported. ${ }^{53} \mathrm{Cis}^{-}$ $\mathrm{Pt}(\mathrm{DMSO})_{2} \mathrm{Cl}_{2}$ was purchased from Sigma-Aldrich and used without further purification. ${ }^{1} \mathrm{H},{ }^{13} \mathrm{C}\left\{{ }^{1} \mathrm{H}\right\}$ nuclear magnetic resonance (NMR) spectra were recorded on a Bruker-400 $\mathrm{MHz}$ spectrometer at ambient temperature in DMSO- $d_{6} \cdot{ }^{195} \mathrm{Pt}$ NMR spectra were recorded on a Varian 500 AR spectrometer in DMF- $d_{7}$. ESI mass spectra were recorded on a Waters LCT Premier XE spectrometer in positive- or negative-ion mode using $\mathrm{MeOH} / \mathrm{H}_{2} \mathrm{O}$ as the solvent. Elemental analyses were performed with an EA 3000 CHNS. Fourier transform infrared spectra were recorded on a FTIR JASCO FT-IR Jasco 680 Plus spectrometer in the region of 4000$400 \mathrm{~cm}^{-1}$ using $\mathrm{KBr}$ pellets. $\mathrm{pH}$ measurements were made using a Corning $240 \mathrm{pH}$ meter equipped with an Aldrich microcombination electrode calibrated with Aldrich standard buffer solutions of $\mathrm{pH} \mathrm{4,} \mathrm{7,} \mathrm{and} 10$.

\subsection{Synthesis of the ligand 1-adamantanemethylcyanamide (1-ADpcydH)}

The 1-adamantanemethylcyanamide (1-ADpcydH) ligand was synthesized from 1-adamantanemethylamine as previously reported. ${ }^{53}$ The pure compound was obtained via re-crystallization from an acetonitrile: pentane ( $2: 5$, volume ratio) solution as yellow needles $(0.138 \mathrm{~g}, 72.63 \%$ yield, and $1 \mathrm{mmol})$. Anal. calc. (\%) for $\mathrm{C}_{12} \mathrm{H}_{18} \mathrm{~N}_{2}$ (190.2847): C, 75.74; H, 9.53; N, 14.72; found (\%): C, 75.69; H, 9.51; N, 14.73. TOF-MS: $191.2927[\mathrm{M}+\mathrm{H}]^{+}$. FTIR: $\nu 2238(\mathrm{~m}, \mathrm{NCNH}) \mathrm{cm}^{-1} .{ }^{1} \mathrm{H}$ NMR (DMSO- $\left.d_{6}\right): \delta 5.59(\mathrm{~s}, 1 \mathrm{H}$, H-NCNH), 2.93 (d, 2H, H-1, 3J 7.2), 1.99 (broad, 3H, H-5), 1.78 (q, 6H, H-3, ${ }^{3} J 7.2$ ), 1.41 (d, 6H, H-2, ${ }^{3} J 7.2$ ). ${ }^{13} \mathrm{C}$ NMR (DMSO- $d_{6}$ ): $\delta 28.5$ (C-5), 33.0 (C-4), 35.8 (C-3), 41.1 (C-2), 50.9 (C-1), 94.5 (HNCN).

\subsection{Synthesis of the ligand 2-[amino(2-phenylpyridine)]-1,4- naphthoquinone (1,4-NQ)}

A solution of 2-phenyl-pyridin-4-ylamine $(0.171 \mathrm{~g}, 1 \mathrm{mmol})$ and triethylamine $(697 \mu \mathrm{L}, 5 \mathrm{mmol})$ in $20 \mathrm{~mL}$ tetrahydrofuran was added dropwise to a solution of 2-bromo-1,4-naphthoquinone $(0.237 \mathrm{~g}, 1 \mathrm{mmol})$ in $20 \mathrm{~mL}$ tetrahydrofuran. The orange solution was stirred for $24 \mathrm{~h}$ at room temperature. The resulting precipitate was removed by filtration and washed with diethylether. The resulting material was purified by silica gel column chromatography ( $1 \%$ methanol/dichloromethane) to provide the product as orange solids $(0.221 \mathrm{~g}, 67.78 \%$ yield, and 1 mmol). Anal. calc. (\%) for $\mathrm{C}_{21} \mathrm{H}_{14} \mathrm{~N}_{2} \mathrm{O}_{2}$ (326.3481): C, 77.29; $\mathrm{H}$,
4.32; N, 8.58; found (\%): C, 77.22; H, 4.30; N, 8.54. TOF-MS: $327.1134[\mathrm{M}+\mathrm{H}]^{+}$. FT-IR: $\nu$ 1712, $1656(\mathrm{C}=\mathrm{O}$ stretch $) \mathrm{cm}^{-1}$. ${ }^{1} \mathrm{H}$ NMR (DMSO- $d_{6}$ ): $\delta 9.99(\mathrm{~s}, 1 \mathrm{H}, \mathrm{NH}), 8.30\left(\mathrm{~d}, 1 \mathrm{H}, \mathrm{H}-\mathrm{b},{ }^{3} J=7.2\right.$ $\mathrm{Hz}$ ), 7.94-8.00 (m, 4H, H-h,i,e), 7.81 (t, 1H, H-k, ${ }^{3} J=7.2 \mathrm{~Hz}$ ), 7.74 (t, $1 \mathrm{H}, \mathrm{H}-\mathrm{j},{ }^{3} \mathrm{~J}=7.2 \mathrm{~Hz}$ ), $7.44-7.50$ (m, 3H, H-d,f), 6.97 (s, 1H, Ha), 6.45 (d, $1 \mathrm{H}, \mathrm{H}-\mathrm{c},{ }^{3} \mathrm{~J}=7.2 \mathrm{~Hz}$ ), 5.83 (s, 1H, H-g). ${ }^{13} \mathrm{C} \mathrm{NMR}$ $\left(\mathrm{DMSO}-d_{6}\right)$ : $\delta 182.0(\mathrm{C}=\mathrm{O}), 180.0(\mathrm{C}=\mathrm{O}), 158.0(\mathrm{Ar}), 153.5(\mathrm{Ar})$, 149.9 (Ar), 138.0 (Ar), 134.5 (Ar), 132.1 (Ar), 128.9 (Ar), 126.8 (Ar), 124.9 (Ar), 123.0 (Ar), 108.8 (C-b), 106.0 (C-e), 102.5 (C-g).

\subsection{Synthesis of the complex 1, cis-Pt(1,4-NQ)(1-ADpcyd)( $\left.\mathrm{H}_{2} \mathrm{O}\right)$}

The ligands of 1-ADpcydH (190 mg, $1 \mathrm{mmol}$ ) and 1,4-NQ (326 mg, $1 \mathrm{mmol}$ ) in $20 \mathrm{~mL}$ ethanol/water $(1: 1$, volume ratio) were added to a stirred solution of $c i s-\left[\mathrm{PtCl}_{2}(\mathrm{DMSO})_{2}\right](423 \mathrm{mg}, 1$ $\mathrm{mmol}$ ) in $10 \mathrm{~mL}$ ethanol. A saturated solution of $\mathrm{KOH}$ in water was added dropwise to the solution until the $\mathrm{pH}$ value was 8.5. The resulting solution was stirred for $72 \mathrm{~h}$ at room temperature. Then, the reaction mixture was filtered and the resulting solution was evaporated under reduced pressure and dissolved in acetonitrile $(10 \mathrm{~mL})$. The addition of $n$-pentane $(40 \mathrm{~mL})$ caused the precipitation of a brown solid. The solid was washed with diethyl ether $(3 \times 10 \mathrm{~mL})$ and dried under vacuum $(0.409 \mathrm{~g}$, $56.31 \%$ yield, and $1 \mathrm{mmol}$ ). Anal. calc. (\%) for $\mathrm{C}_{33} \mathrm{H}_{32} \mathrm{~N}_{4} \mathrm{O}_{3} \mathrm{Pt}$ (727.7162): C, 54.47; H, 4.43; N, 7.70; found (\%): C, 54.43; H, 4.41; N, 7.66. TOF-MS: $750.7059[\mathrm{M}+\mathrm{Na}]^{+}$. FT-IR: $\nu$ 1689, 1632 $\left(\mathrm{C}=\mathrm{O}\right.$ stretch), $2146(\mathrm{~m}, \mathrm{NCN}) \mathrm{cm}^{-1} \cdot{ }^{1} \mathrm{H}$ NMR (DMSO- $\left.d_{6}\right): \delta 9.89$ $(\mathrm{s}, 1 \mathrm{H}, \mathrm{NH}), 8.49$ (d, $\left.1 \mathrm{H}, \mathrm{H}-\mathrm{c},{ }^{3} J=7.2 \mathrm{~Hz}\right), 8.20$ (d, $1 \mathrm{H}, \mathrm{H}-\mathrm{b},{ }^{3} J=$ $7.2 \mathrm{~Hz}$ ), 8.00-8.09 (m, 4H, H-h,i,e), 7.75-7.80 (m, 2H, H-k,j), 7.24-7.29 (m, 2H, H-d,f), 6.81 (s, 1H, H-a), 5.79 (s, 1H, H-g), 3.64 (coordinated water), 2.79 (d, 2H, H-1, ${ }^{3} J$ 7.2), 1.91 (broad, $3 \mathrm{H}, \mathrm{H}-5$ ), 1.67 (q, 6H, H-3, ${ }^{3} J$ 7.2), 1.13 (d, 6H, H-2, ${ }^{3} J 7.2$ ). ${ }^{13} \mathrm{C}$ NMR (DMSO- $\left.d_{6}\right): \delta 181.1(\mathrm{C}=\mathrm{O}), 179.9(\mathrm{C}=\mathrm{O}), 158.1(\mathrm{Ar}), 153.4$ (Ar), 150.0 (Ar), 138.5 (Ar), 135.0 (Ar), 132.9 (Ar), 130.0 (Ar), 127.0 (Ar), 124.0 (Ar), 122.0 (Ar), 112.0 (NCN), 109.9 (C-b), 105.8 (C-e), 103.2 (C-g), 47.91 (C-1), 40.9 (C-2), 34.1 (C-3), 31.0 (C-4), 27.0 (C5). ${ }^{195} \mathrm{Pt}\left\{{ }^{1} \mathrm{H}\right\}$ NMR (107.6 MHz, DMF- $\left.d_{7}\right): \delta-2794 \mathrm{ppm}$.

\subsection{Synthesis of the complex 2 , cis-Pt(1,4-NQ)(1-ADpcyd)(G): interaction of cis-Pt(II) complex 1 with guanine}

Complex 1 ( $1 \mathrm{mmol}$ ) and guanine (5 mmol) were dissolved in $5 \mathrm{~mL} \mathrm{DMF}$ and stirred at $40{ }^{\circ} \mathrm{C}$ for $24 \mathrm{~h}$. The reaction was followed by ${ }^{195} \mathrm{Pt}$ NMR spectroscopy. The ${ }^{195} \mathrm{Pt}$ NMR spectra were recorded in DMF with an insert $\mathrm{D}_{2} \mathrm{O}$ tube. The $\mathrm{pH}$ of the reaction mixtures was monitored during the reaction and varied from 6.4 to 7.2. After $24 \mathrm{~h}$, the unreacted guanine was removed by filtration. The solution was rotary-evaporated to dryness to give the crude product. The residue was dissolved in acetonitrile $(10 \mathrm{~mL})$ and $n$-hexane $(50 \mathrm{~mL})$ was added to produce the precipitation of light brown solids $(0.754 \mathrm{~g}, 87.65 \%$ yield, and 1 mmol). Anal. calc. (\%) for $\mathrm{C}_{38} \mathrm{H}_{35} \mathrm{~N}_{9} \mathrm{O}_{3} \mathrm{Pt}$ (860.8270): C, 53.02; $\mathrm{H}$, 4.10; N, 14.64; found (\%): C, 52.98; H, 4.08; N, 14.61. TOF-MS: $883.8168[\mathrm{M}+\mathrm{Na}]^{+} .{ }^{1} \mathrm{H}$ NMR (DMSO- $\left.d_{6}\right): \delta 11.29(\mathrm{~s}, 1 \mathrm{H}, \mathrm{NH} 1)$, 10.90 (s, 1H, NH9), 9.89 (s, 1H, NH), 8.49 (d, 1H, H-c, ${ }^{3} J=7.2$ $\mathrm{Hz}$ ), 8.34 (s, 1H, H-8), 8.20 (d, 1H, H-b, ${ }^{3} J=7.2 \mathrm{~Hz}$ ), 8.00-8.09 (m, 4H, H-h,i,e), 7.75-7.80 (m, 2H, H-k,j), 7.24-7.29 (m, 2H, Hd,f), 6.92 (s, 2H, H-NH ${ }_{2}$ ), 6.81 (s, 1H, H-a), 5.79 (s, 1H, H-g), 2.79 
(d, 2H, H-1, ${ }^{3} J 7.2$ ), 1.91 (broad, 3H, H-5), 1.67 (q, 6H, H-3, ${ }^{3} J 7.2$ ), $1.13\left(\mathrm{~d}, 6 \mathrm{H}, \mathrm{H}-2,{ }^{3} J\right.$ 7.2). ${ }^{13} \mathrm{C}$ NMR (DMSO- $\left.d_{6}\right): \delta 181.0(\mathrm{C}=\mathrm{O})$, 178.6 (C=O), 158.0 (Ar), 156.1, $154.0(\mathrm{Ar}), 151.9(\mathrm{Ar}), 149.9(\mathrm{Ar})$, 138.6 (Ar), 136.6 (Ar), 134.9 (Ar), 132.1 (Ar), 129.9 (Ar), 126.6 (Ar), 123.5 (Ar), 122.0 (Ar), 112.1 (NCN), 109.9 (C-b), 107.2, 105.5 (Ce), 102.9 (C-g), 48.0 (C-1), 41.0 (C-2), 34.2 (C-3), 31.0 (C-4), 27.1 (C-5). ${ }^{195} \mathrm{Pt}\left\{{ }^{1} \mathrm{H}\right\}$ NMR (107.6 MHz, DMF- $\left.d_{7}\right): \delta-3229 \mathrm{ppm}$.

\subsection{Stability tests}

The stability of complex 1 was tested by dissolving it in PBS buffer/0.5\% DMSO and keeping for $72 \mathrm{~h}$ at $37{ }^{\circ} \mathrm{C}$. Briefly, $10 \mu \mathrm{L}$ of the solution was injected into an HPLC system (Thermo, USA) connected to a UV/Vis spectrophotometer. A Hypersil Gold Dim $(100 \times 2.1 \mathrm{~mm}$, Thermo, USA $)$ reversed-phase column was used at a flow rate of $0.7 \mathrm{~mL} \mathrm{~min}^{-1}$.

\subsection{Cell culture}

Human MCF-7 breast, HepG-2 liver hepatocellular carcinoma, and HT-29 colon cancer cell lines were obtained from the American Type Culture Collection (ATCC, USA). All reagents and cell culture media were purchased from Gibco Company (Germany). The cells were maintained in Dulbecco's Modified Eagle Medium (DMEM) supplemented with $10 \% \mathrm{FBS}, 100 \mathrm{IU} \mathrm{mL}^{-1}$ of penicillin, $100 \mu \mathrm{g} \mathrm{mL} \mathrm{m}^{-1}$ of streptomycin, and $2 \mathrm{mM}$ of Glutamax at $37{ }^{\circ} \mathrm{C}$ in a humidified incubator at $5 \% \mathrm{CO}_{2}$. The adherent cultures were grown as monolayers and were passaged once in 4-5 days by trypsinizing them with $0.25 \%$ trypsin-EDTA.

\subsection{Cytotoxicity}

The growth inhibitory effect toward tumor cells was evaluated by means of the MTT (3-(4,5-dimethylthiazol-2-yl)-2,5diphenyltetrazolium bromide) tetrazolium reduction assay. ${ }^{54}$ Stock solutions of free ligands and complex 1 were prepared by dissolving the compounds in DMSO $(0.008 \mathrm{mM})$ that for cisplatin was prepared by dissolving in RPMI-1640 medium. The stocks were further diluted with the respective medium containing $10 \%$ FBS $(0.02-10 \mu \mathrm{M})$ before addition to the cells. Cells were trypsinized with $0.25 \%$ trypsin-EDTA and counted with $0.4 \%$ trypan blue. The cells were seeded at a concentration of 7500 cells $/ 100$ $\mu \mathrm{L}$ per well and grown for $24 \mathrm{~h}$ at $37{ }^{\circ} \mathrm{C}$ in a humidified incubator. After $24 \mathrm{~h}$, the medium was removed and replaced with fresh medium containing the compound to be studied at the appropriate concentration. Triplicate cultures were established for each treatment. After $72 \mathrm{~h}$, each well was treated with $10 \mu \mathrm{L}$ of a $5 \mathrm{mg} \mathrm{mL}{ }^{-1}$ MTT saline solution, and, following $5 \mathrm{~h}$ of incubation, $100 \mu \mathrm{L}$ of a sodium dodecylsulfate solution in $\mathrm{HCl}(0.01$ M) was added. The optical absorbance of each well (96-well plates) was quantified using EnVision multilabel plate readers (PerkinElmer, Waltham, MA, USA) at $450 \mathrm{~nm}$ wavelength. The mean absorbance values were then calculated and exported to Graphpad Prism version 6.0 for Windows and plotted in the logarithmic form to determine the $\mathrm{IC}_{50}$ values. The $\mathrm{IC}_{50}$ value was calculated as the concentration reducing the proliferation of the cells by $50 \%$ and is presented herein as the mean $( \pm \mathrm{SE})$ of three independent experiments each with triplicates. $P<0.05$ was considered to be statistically significant.

\subsection{Cellular platinum accumulation}

Cellular accumulation of complex 1 and cisplatin was measured in HT-29 cells. $1 \times 10^{6}$ cells were seeded in $60 \mathrm{~mm}$ tissue culture dishes. After incubation overnight at $37{ }^{\circ} \mathrm{C}$, the cells were treated with complex 1 or cisplatin for $1 \mathrm{~h}$ at a final concentration of $10 \mu \mathrm{M}$ at $0.5 \%$ DMSO. The cell monolayers at the end of the incubation with complex 1 or cisplatin were washed twice with PBS (phosphate buffered saline), trypsinized, and harvested into appropriate media. Cell suspensions were centrifuged, the pellets were digested with $12 \mathrm{M} \mathrm{HCl}$, and the platinum content was analyzed by ICP-MS. All the experiments were performed in triplicate.

\subsection{DNA platination}

DNA platination was performed by using complex $\mathbf{1}$ and cisplatin $(10 \mu \mathrm{M})$ in HT-29 cells as previously reported. ${ }^{39}$

\subsection{Computational details}

Density functional theory (DFT) calculations were carried out using the 2014.01 version of the Amsterdam Density Functional (ADF) program ${ }^{55}$ developed by Baerends and co-workers. ${ }^{56-60}$ Electron correlation was treated within the local density approximation (LDA) in the Vosko-Wilk-Nusair parametrization. ${ }^{61}$ The DFT-D method consisting of BP86- $\mathrm{D}^{62}$ was used for all calculations to compensate for the incapacity of the generalized gradient approximation BP86 (ref. 63-66) functional to describe the dispersion effects correctly besides the hybrid-type B3LYP. ${ }^{67,68}$ The atom electronic configurations were described by a triple- $\zeta$ Slater-type orbital (STO) basis set for $\mathrm{H} 1 \mathrm{~s}, \mathrm{C} 2 \mathrm{~s}$ and $2 \mathrm{p}, \mathrm{N} 2 \mathrm{~s}$ and $2 \mathrm{p}, \mathrm{O} 2 \mathrm{~s}$ and $2 \mathrm{p}$ augmented with a $3 \mathrm{~d}$ single- $\zeta$ polarization for $\mathrm{C}, \mathrm{N}$, and $\mathrm{O}$ atoms and with a $2 \mathrm{p}$ single- $\zeta$ polarization for $\mathrm{H}$ atoms. A triple- $\zeta$ STO basis set was used for the Pt $5 \mathrm{~d}$ and $6 \mathrm{~s}$ augmented with a single- $\zeta 6 \mathrm{p}$ polarization function for Pt. For the heavy Pt atom, the scalar relativistic zero-order regular approximation (ZORA) was used, with the associated optimized valence basis set. The BP86-D calculations were performed assuming the frozen-core approximation up to 1s for C, $3 \mathrm{p}$ for the first-row metals, and $4 \mathrm{f}$ for $\mathrm{Pt}^{56-60}$ Full geometry optimizations were carried out using the analytical gradient method implemented by Versluis and Ziegler. ${ }^{69}$ Vibrational frequency calculations were performed on all the optimized geometries to verify that these structures were true minima on the potential energy surface. ${ }^{\mathbf{7 0}, 71}$ All the energy values reported in the ESI $\dagger$ include zero-point energy correction. Representations of the orbitals and of the molecular structures were done by using the ADF-GUI ${ }^{55}$ and the MOLEKEL4 programs ${ }^{72}$ respectively. The natural population-based and Wiberg bond indices (NPAI and WBI, respectively) ${ }^{73}$ were obtained from calculations implemented in the NBO 6.0 program. ${ }^{74,75}$

\section{Results and discussion}

\subsection{Synthesis and characterization}

Complex 1 was prepared in high yield by the 1-ADpcydH and 1,4-NQ ligands and complex cis-[Pt(DMSO $\left.)_{2} \mathrm{Cl}_{2}\right]$ in ethanol at $\mathrm{pH}$ 
$\sim 8.5$ (Scheme 1). The cis-Pt(II) complex 1 was a brown solid and was soluble in acetonitrile, ethanol, chloroform, acetone, DMF, and DMSO.

The 1-ADpcydH and 1,4-NQ ligands and cis-Pt(II) complex 1 were characterized by elemental analyses, and IR, multinuclear NMR $\left({ }^{1} \mathrm{H},{ }^{13} \mathrm{C}\right.$, and $\left.{ }^{195} \mathrm{Pt}\right)$, and mass spectrometry. The ESI-TOF MS spectra of 1-ADpcydH and 1,4-NQ showed peaks centered at $m / z=191.2927$ and 327.1134, corresponding to $[\mathrm{M}+\mathrm{H}]^{+}$.
Furthermore, the ESI-TOF MS spectra of cis-Pt(II) complex 1 showed peaks centered at $\mathrm{m} / z=727.7162$ with the typical platinum isotope pattern, corresponding to $[\mathrm{M}+\mathrm{Na}]^{+}$(Fig. S1$\mathrm{S} 3 \dagger)$.

The $\nu(\mathrm{NCN})$ band of 1-ADpcydH ligand was observed at $2238 \mathrm{~cm}^{-1}$, which was shifted to lower frequency, $2146 \mathrm{~cm}^{-1}$, upon the coordination of cyanamide through the cyano nitrogen to $\mathrm{Pt}(\mathrm{II})$ in the cis-Pt(II) complex 1. Deprotonation of the<smiles>O=C1C=C(Br)C(=O)c2ccccc21</smiles><smiles>CC(C)C</smiles><smiles>O=C1C=C(Nc2ccnc(-c3ccccc3)c2)C(=O)c2ccccc21</smiles><smiles>[Li]</smiles><smiles>NC1=CC(=O)c2ccccc2C1=O</smiles><smiles></smiles>

Complex 1<smiles></smiles>

Complex 2

Scheme 1 Synthetic pathways of the ligand 1,4-NQ and the complex 1. Reagents and conditions: (i) triethylamine, $\mathrm{THF}, 0{ }^{\circ} \mathrm{C}$ to $\mathrm{rt}, 24 \mathrm{~h}$. (ii) $1-\mathrm{AD}-$ pcydH, cis- $\left[\mathrm{PtCl}_{2}(\mathrm{DMSO})_{2}\right]$, ethanol/water (1 : 1, volume ratio), $\mathrm{KOH}(\mathrm{pH}=8.5), \mathrm{rt}, 72 \mathrm{~h}$. (iii) guanine, $24 \mathrm{~h}, \mathrm{DMF}, 40{ }^{\circ} \mathrm{C}$. 
cyanamide group shifted $\nu$ (NCN) to lower frequencies, such as carbodiimides, meaning form $\mathrm{B}$ was the main involvement with the cyanamide anion group. The resonance form A had a nitrile stretching frequency similar to the neutral cyanamide (Scheme 2). ${ }^{39}$ Complex 1 showed $\nu(\mathrm{OH})$ and $\gamma\left(\mathrm{H}_{2} \mathrm{O}\right)$ bands at 3446 and $1141 \mathrm{~cm}^{-1}$, respectively, due to the coordinated water. ${ }^{76}$

The ${ }^{1} \mathrm{HNMR}$ spectra of the free ligands and cis-Pt(II) complex $\mathbf{1}$ are shown in Fig. S4-S6. $\dagger$ The $\mathrm{NH}$ proton of 1-ADpcydH ligand at $5.59 \mathrm{ppm}$ disappeared in the cis-Pt(II) complex 1 due to the coordination of the cyanamide group to $\mathrm{Pt}(\mathrm{II})$ in complex $\mathbf{1}$. The proton $\mathrm{H}-\mathrm{C}$ of 1,4-NQ resonances underwent the largest shift from $6.45 \mathrm{ppm}$ in the free ligand 1,4-NQ to $8.49 \mathrm{ppm}$ in $\mathrm{Pt}$ (II) complex 1 , indicating a strong relationship with the geometry of the molecule. Such a quite large downfield shift originated from the shielding exerted on $\mathrm{H}-\mathrm{C}$ by the $\mathrm{N}=\mathrm{C}=\mathrm{N}$ bond of $1-\mathrm{ADp}$ cydH and this was possible only in the cis isomer (Scheme 1). Therefore, the cis configuration of the Pt(II) complex 1 could be carefully inferred. In the ${ }^{1} \mathrm{HNMR}$ spectrum of the cis-Pt(II) complex 1, the other signals were shifted, with respect to the free ligands, which confirmed the formation of $\mathrm{Pt}(\mathrm{II})$ complex.

In the ${ }^{13} \mathrm{C}$ spectra of the cis-Pt(II) complex $\mathbf{1}$, the signals were shifted compare to the free ligands (Fig. S7-S9†).

The ${ }^{195} \mathrm{Pt}$ NMR of cis-Pt(II) complex 1 revealed a singlet at -2794 ppm, indicating the presence of a single solution species, and this deduction was individually confirmed by ${ }^{1} \mathrm{H}$ and ${ }^{13} \mathrm{C}$ NMR spectroscopy. Moreover, this chemical shift range was assignable to the platinum(II) complexes having $\mathrm{N}^{\wedge} \mathrm{N}^{\wedge} \mathrm{C}^{\wedge} \mathrm{O}$ as ligands (Fig. S10†). ${ }^{77}$

\subsection{Interaction cis-Pt(II) complex 1 with guanine (G)}

The activity of cisplatin is mostly, in terms of DNA damage, affected through its ability to bind to the N7 position of guanine bases. Therefore, the reaction of complex $\mathbf{1}$ at micromolar concentrations with 5 equiv. of guanine was studied. During the reaction, the $\mathrm{pH}$ of the unbuffered reaction mixtures differed between 6.4 and 7.2, approximately close to physiological conditions. The reaction was followed by ${ }^{195} \mathrm{Pt}$ NMR spectroscopy (Fig. 1). Comparison of the ${ }^{195} \mathrm{Pt}$ NMR spectra obtained during the reaction with that at $t=0$ confirmed the binding of the Pt(II) complex 1 to the N7 guanine. At $t=0$, the ${ }^{195} \mathrm{Pt} \mathrm{NMR}$ spectra of 1 revealed one peak at $-2796 \mathrm{ppm}$, indicating the presence of a single solution species. As the reaction proceeded, ${ }^{195} \mathrm{Pt}$ NMR of reaction showed two solution species at -2796 and $-3230 \mathrm{ppm}$, where the signal at $-2796 \mathrm{ppm}$ decreased and the new signal at $-3230 \mathrm{ppm}$ increased in intensity. Furthermore, the signal at $-3230 \mathrm{ppm}$ could be assigned to the chemical shift range of platinum(II) complexes having $\mathrm{N}^{\wedge} \mathrm{N}^{\wedge} \mathrm{N}^{\wedge} \mathrm{C}$ as ligands. ${ }^{78}$ The chemical shift was consistent with substitution of $\mathrm{O}$ of $\mathrm{H}_{2} \mathrm{O}$ with $\mathrm{N} 7$ of guanine. After $24 \mathrm{~h}$, the final product showed only one signal at $-3230 \mathrm{ppm}$. The final product, cis-Pt(1,4-NQ)(1-ADpcyd)(G), 2, was also confirmed by mass (Fig. 2) and ${ }^{1} \mathrm{H}$ and ${ }^{13} \mathrm{C}$ NMR spectra (Fig. S11 and S12 $\dagger$ ). The mass spectrum exhibited peaks centered at $\mathrm{m} / \mathrm{z}=883.8168$ with the typical platinum isotope pattern corresponding to $[\mathrm{M}+$ $\mathrm{Na}]^{+}$. The ${ }^{1} \mathrm{H}$ spectrum of complex 2 revealed one major aromatic $\mathrm{H} 8$ guanine as a singlet at $8.34 \mathrm{ppm}$ and two singlets at 10.90 and 11.29 ppm for NH9 and NH1 guanine, respectively. The ${ }^{195} \mathrm{Pt}$ NMR of cis-Pt(II) complex 2 revealed a singlet at -3229 ppm (Fig. S13†).

\subsection{Stability of complex 1}

The stability of the cis-Pt(II) complex 1 in PBS/DMSO (0.5\%) solution was studied by HPLC-UV at $37{ }^{\circ} \mathrm{C}$. The results confirmed that complex 1 was stable in physiological conditions over 72 h (Fig. S14†).

\subsection{In vitro cytotoxicity studies}

The effect of the free ligands 1-ADpcydH and 1,4-NQ and also complex 1 on a panel of human cancer cell lines, including MCF-7 breast, HepG-2 liver hepatocellular carcinoma, and HT29 colon adenocarcinoma, was examined using the MTT assay. The cytotoxicity parameters, in terms of $\mathrm{IC}_{50}$ obtained after $72 \mathrm{~h}$ exposure, are presented in Table 1 and Fig. S15. $\dagger$ Complex 1 exhibited lower $\mathrm{IC}_{50}$ values $\left(\mathrm{IC}_{50} 0.56-7.25 \mu \mathrm{M}\right)$ against MCF-7, HepG-2, and HT-29 than the corresponding 1$\mathrm{ADpcydH}$ and 1,4-NQ ligands and also than cisplatin.

(a)

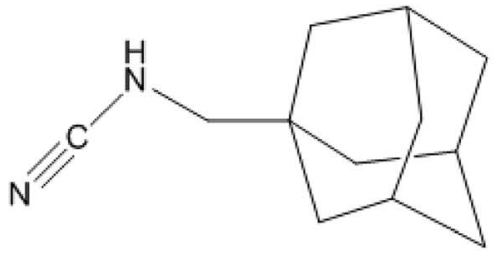

(b)

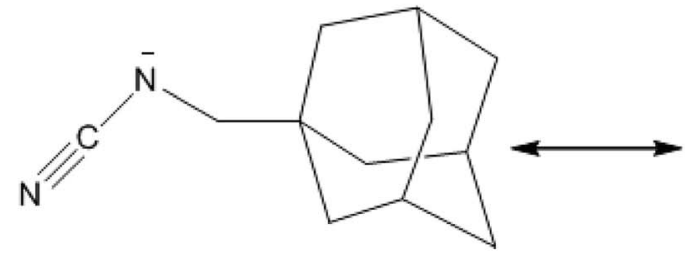

A

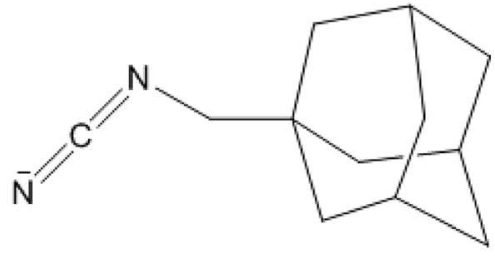

B

Scheme 2 (a) The structure of 1-adamantanemethylcyanamide (1-ADpcydH). (b) Resonance structures of the 1-adamantanemethylcyanamide anionic form. 

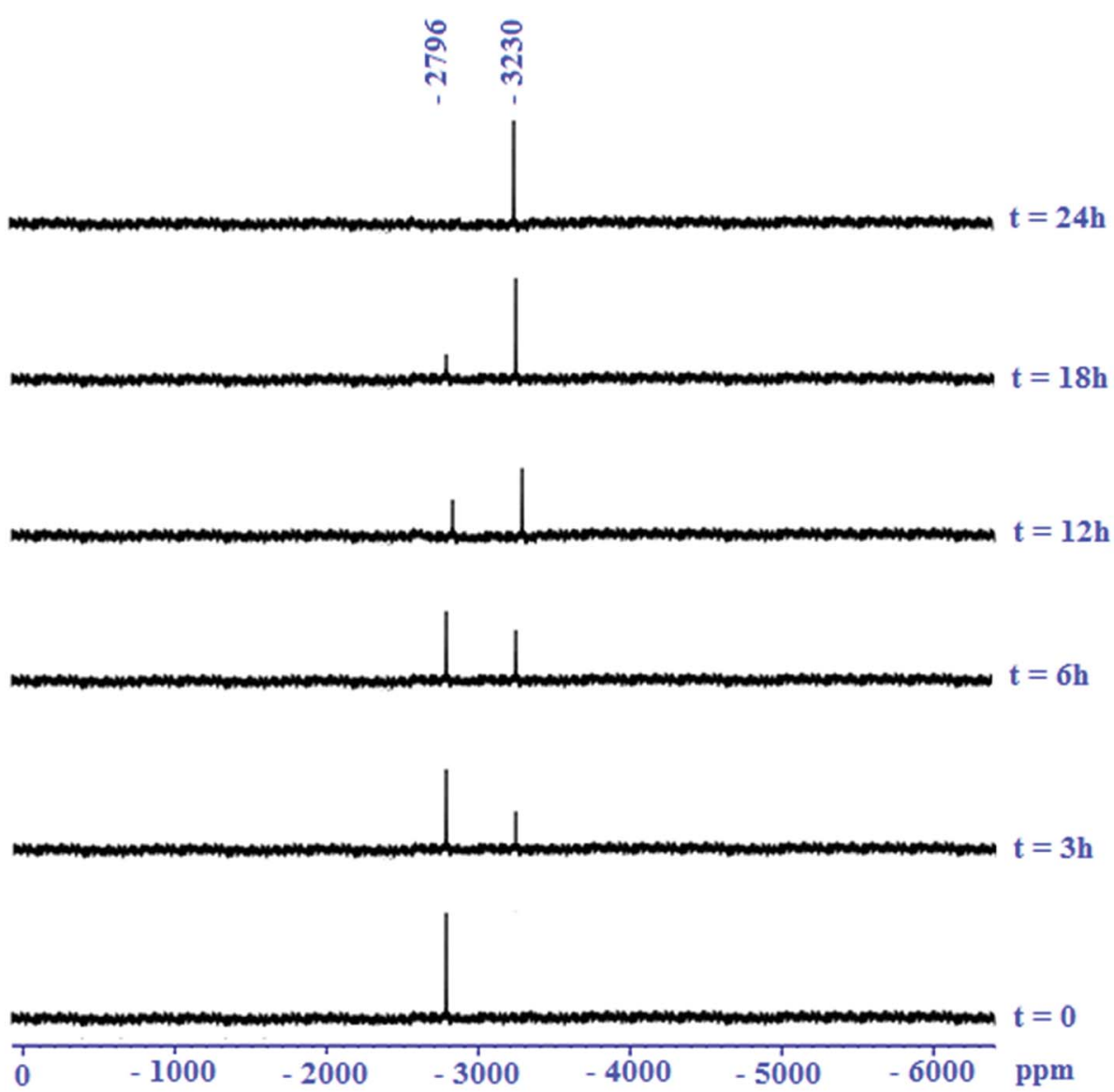

Fig. 1 Reaction of cis-Pt(॥) complex 1 with guanine as followed by ${ }^{195} \mathrm{Pt}$ NMR spectroscopy (conditions as mentioned in the Experimental section).

Remarkably, the lowest $\mathrm{IC}_{50}$ value for complex 1 against HT-29 was $0.56 \mu \mathrm{M}$, which displayed approximately a 4.5 -fold increase compared with cisplatin, thus indicating its higher potency. The cytotoxicity of complex 1 against the HepG-2 was higher than that of the platinum(II) complexes with 8-hydroxyquinoline $\left(\mathrm{IC}_{50}\right.$ 7.79-18.54 $\mu \mathrm{M}){ }^{79}$

\subsection{Intracellular platinum accumulation in HT-29 cells}

The cellular accumulation of the cis-Pt(II) complex 1 was studied and compared to that of cisplatin. The amount of Pt associated was determined using ICP-MS with HT-29 cells incubated after $1 \mathrm{~h}$ with complex 1 or cisplatin. It was found that complex 1 was highly accumulated when compared to cisplatin in HT-29 cell lines. The accumulation of complex 1 in HT-29 cells was 12.25 \pm 0.10 fmol of $\mathrm{Pt}(\mathrm{II})$, which was greater than that of cisplatin, containing $0.26 \pm 0.05$ fmol of $\mathrm{Pt}(\mathrm{II})$.

\subsection{DNA platination}

As the main target for the Pt(II) complexes within the cell is the nuclear DNA, so the DNA binding of complex 1 in HT-29 cell line was studied and compared with cisplatin (Fig. 3). In effect, complex 1 showed a high degree of DNA platination in the HT29 cell line compared with cisplatin, which was in agreement with the accumulation data.
Overall, the high levels of complex 1 bound to the DNA in HT-29 cell and interaction with guanine suggest that the direct attack of nucleotides on cis-Pt(II) complex 1 may be of importance in the mechanism of action for this $\mathrm{Pt}(\mathrm{II})$ complex.

\subsection{Theoretical investigation}

3.7.1. Geometry optimizations. The cis-Pt $(1,4-\mathrm{NQ})(1-$ ADpcyd)(L) ( $\mathrm{L}=\mathrm{H}_{2} \mathrm{O}$, guanine) complexes (Scheme 3) were synthesized in aqueous solution as discussed earlier and labeled 1 and 2 complexes for $\mathrm{H}_{2} \mathrm{O}$ and guanine, respectively. In both complexes 1 and 2, the $\mathrm{Pt}(\mathrm{II})$ cation was surrounded by two $\mathrm{N}$, one $\mathrm{C}$, and one $\mathrm{O}$ atom in the case of the $\mathrm{H}_{2} \mathrm{O}$ ligand and by three $\mathrm{N}$ and one $\mathrm{C}$ atom in the case of the guanine ligand as demonstrated in Fig. 4.

The full geometry optimizations without symmetry constraints were carried out on the neutral 1 and 2 complexes having 16-MVE (metal valence electrons) in their singlet and triplet spin state to complement the experimental studies. The triplet structures were higher in energy than their corresponding singlet structures by about $40 \mathrm{kcal} \mathrm{mol}^{-1}$; thus they are not discussed within this study. The Pt-N(1), Pt-N(2) and Pt-C(1) bond distances in both investigated complexes were comparable (Table 2). Indeed, for complex 1, the Pt-O$\left(\mathrm{H}_{2} \mathrm{O}\right)$ bond length of 2.253 (BP86-D) or $2.124 \AA$ (B3LYP), respectively, was nearly similar to the experimental ones of $2.149 \AA$, while the $\mathrm{Pt}-\mathrm{N}(1), \mathrm{Pt}-\mathrm{N}(2)$ and 

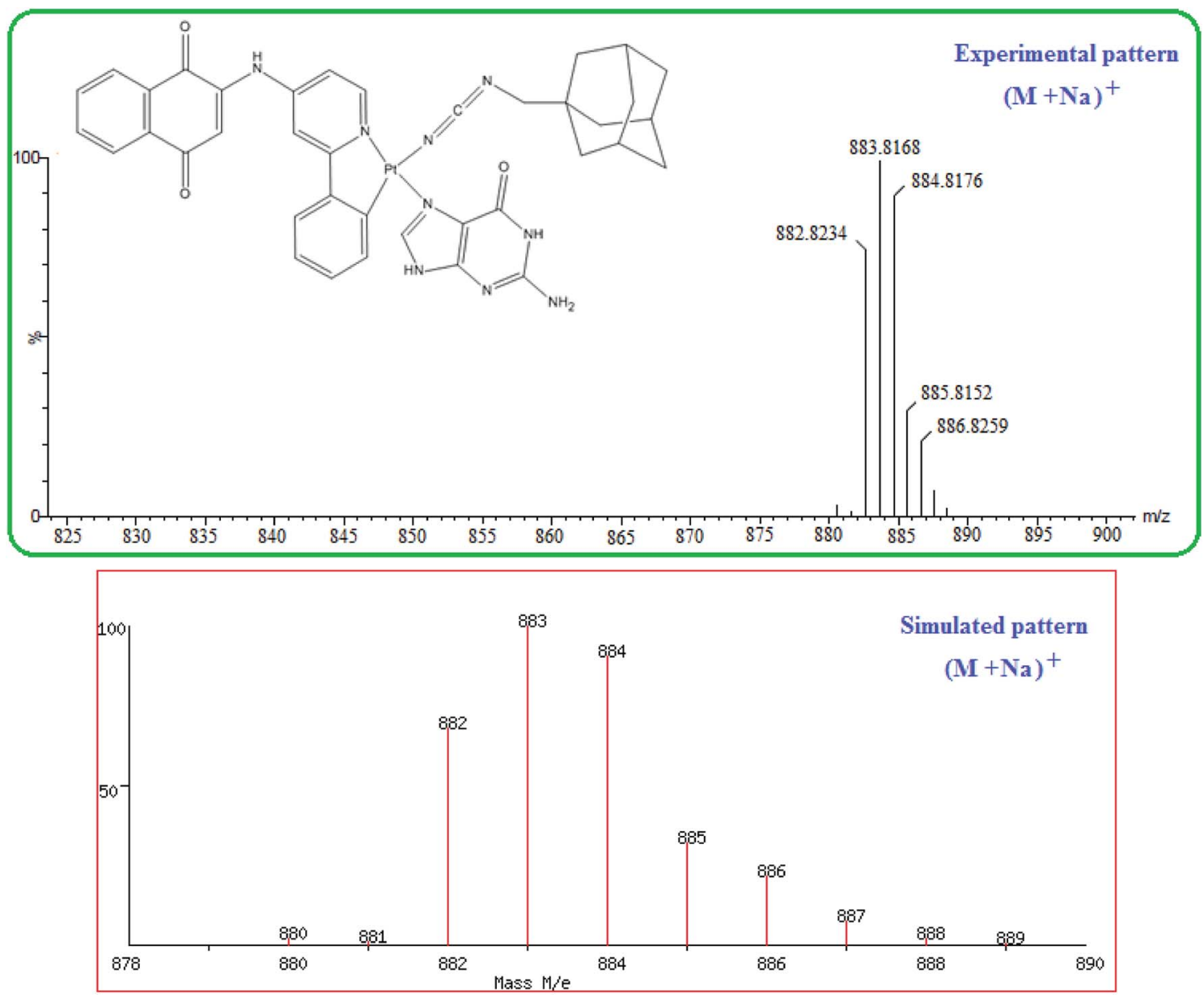

Fig. 2 Mass spectrum of cis-Pt(1,4-NQ)(1-ADpcyd)(G).

Table 1 In vitro antitumor activity ${ }^{a}$

\begin{tabular}{llll}
\hline Compounds & & & \\
\hline HepG-2 & HT-29 & MCF-7 & \\
\hline$>100$ & $>100$ & $>100$ & IC 50 1-ADpcydH \\
$>100$ & $>100$ & $>100$ & $1,4-\mathrm{NQ}$ \\
$7.25 \pm 0.05$ & $0.56 \pm 0.03$ & $1.52 \pm 0.05$ & $\mathbf{1}$ \\
$8.32 \pm 0.08$ & $2.52 \pm 0.05$ & $7.35 \pm 0.07$ & Cisplatin
\end{tabular}

${ }^{a}$ The compounds were dissolved in $0.1 \%$ of DMSO and diluted with water, while cisplatin was dissolved in water. Cells were treated for $72 \mathrm{~h}$ with increasing concentrations of the tested compounds. $\mathrm{IC}_{50}$ values were calculated as mean values obtained from three independent experiments and presented with their standard deviations.

Pt-C(1) were 2.108, 2.286, and $2.059 \AA$ (BP86-D) or 2.003, 2.223, and $1.995 \AA$ A (B3LYP), which were longer (BP86-D) and comparable (B3LYP) to those of the experimental values of related $\mathrm{Pt}$ (II) systems. ${ }^{80-83}$ For complex 2, the Pt-N(7) bond length was 2.146 (BP86-D) or $2.052 \AA$, where the B3LYP value was comparable to the experimental ones reported in the literature, inversely to the case of the BP86-D one, which was calculated to be longer. ${ }^{81}$ For both structures, the C(1)-Pt-N(2) $\left(174^{\circ}\right)$ and N(1)-Pt-N(7) $\left(178^{\circ}\right)$ or $\mathrm{N}(1)-\mathrm{Pt}-\mathrm{O}\left(177^{\circ}\right)$ bond angles were quite linear around the $\mathrm{Pt}(\mathrm{II})$ center. The computed geometric parameters place emphasis on

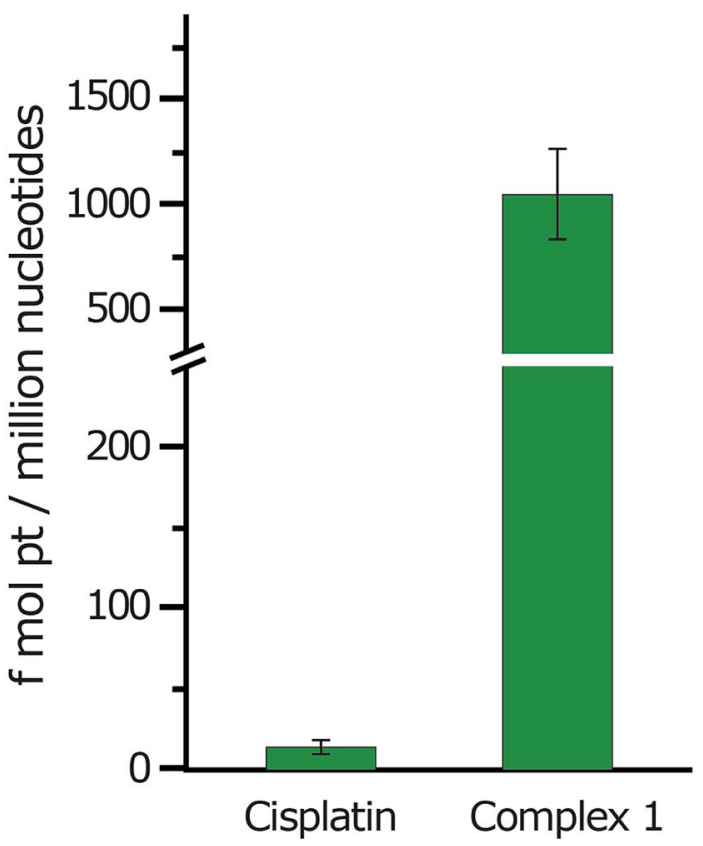

Fig. 3 Intracellular DNA platination of cisplatin and complex 1 in the $\mathrm{HT}-29$ cell line after $1 \mathrm{~h}$ incubation at $10 \mu \mathrm{M}$ final concentration. 

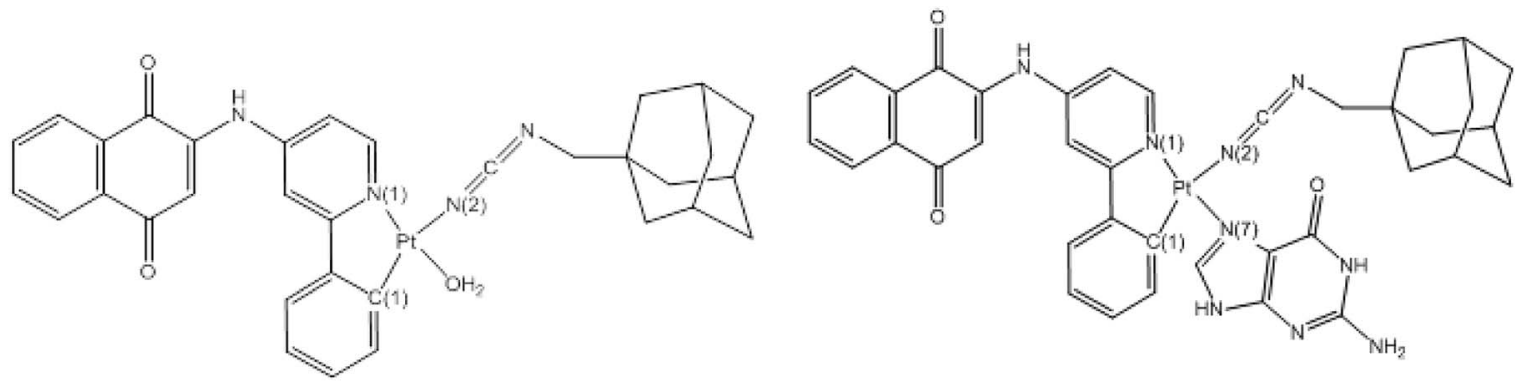

Scheme 3 Atom numbering adopted for the Pt center's environment.

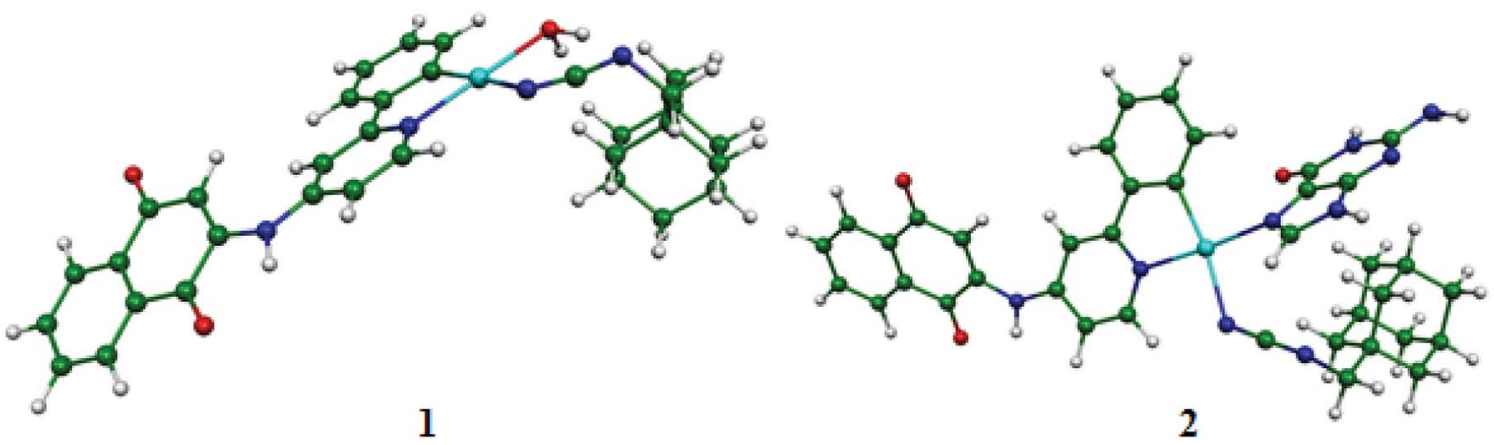

Fig. 4 The lowest BP86-optimized structures for complexes 1 and 2 of the singlet state.

a slightly deformed square planar $\mathrm{ML}_{4}$ geometry having the 16MVE configuration, as witnessed by the $\mathrm{N}(1)-\mathrm{N}(2)-\mathrm{O}-\mathrm{C}(1)$ and $\mathrm{N}(1)-\mathrm{N}(2)-\mathrm{N}(7)-\mathrm{C}(1)$ dihedral angles of about $0^{\circ}$ for complexes 1 and 2, respectively. Relatively, the deformation around the metal cation of complex $\mathbf{1}$ was more marked than that of complex $\mathbf{2}$.

A Mulliken population analysis of the MO plots for complex 2 showed that the two highest HOMO and HOMO-1 were metalligand based with a small metallic contribution as presented in Fig. 5. However, the HOMO was purely metallic. The LUMO was chiefly a ligand orbital, thus the reduction should not affect its molecular structure. Furthermore, the HOMO-3 and the HOMO4 showed $\sigma$ and $\pi \mathrm{Pt}-\mathrm{C}(1)$ bonding, respectively.

For complex 1, the HOMO was principally a ligand orbital, while the HOMO-1 was purely metallic and the LUMO was principally orbital, as sketched out in Fig. 5. It is worth noting that there was no participation of the water molecules in these crucial orbitals. Accordingly, oxidation and reduction of the neutral should not affect the molecular structure.

3.7.2. NBO analysis. The NBO analysis revealed a natural charge of +0.662 and +0.679 (BP86-D) or 0.728 and +0.744 (B3LYP) for Pt(II) cations in $\mathbf{1}$ and 2, respectively, putting emphasis on strong interactions between the metal center and its surrounding ligands. The charge was weakly influenced by the ligand change. It is worth noting that the $\mathrm{Pt}(\mathrm{II})$ charges for complexes 1 and 2 obtained by B3LYP were more important than those obtained by BP86-D. Stronger electron density was localized on the oxygen atom in $\mathbf{1}$ than that localized on the nitrogen one of guanine in 2 as illustrated by the difference between their negative charges of -0.898 and -0.413 (BP86-D) or -0.917 and -0.421 (B3LYP), respectively.
The $\mathrm{Pt}(\mathrm{II})$ charges in both complexes $\mathbf{1}$ and $\mathbf{2}$ were comparable to that computed in previous works, particularly those obtained by B3LYP. ${ }^{84,85}$ There was an increase in negative charge at the nitrogen $\mathrm{N}(7)$ atom of guanine from -0.39 (free guanine) to -0.42 (complex 2), corresponding to an increase in electron density at this nitrogen center contained in complex 2. This electron density enhancement was in accord with the electron transfer from the Pt metal occupied orbitals responsible for the backdonation into the vacant $\pi^{*}$ antibonding orbital of guanine as illustrated by the orbital occupations in Table 2 . Whereas, there was an important decrease in negative charge at the oxygen atom of $\mathrm{H}_{2} \mathrm{O}$ encountered in complex 1 from -0.96 (BP86-D) to -0.89 , corresponding to a slight decrease in electron density at this center in agreement with the $\sigma$-donor character of the $\mathrm{H}_{2} \mathrm{O}$ ligand as illustrated by the $\sigma$-donation (Table 2), where the lone pair localized on the oxygen has lost 0.13e (its occupation is 1.87 after interaction as shown in Table 2). The natural electronic configuration of the Pt center (Table 2) obtained by both BP86-D and B3LYP methods showed that the major electronic transfers arose from back-donation from the occupied $5 \mathrm{~d}$ orbitals of the Pt, which were significantly depopulated compared to the donation from the $\sigma$ lone pair of the oxygen in $\mathbf{1}$ and the lone pair of nitrogen in 2 to the Pt 6s orbital. As a result, the Pt(center) NAO configuration exhibited significant $5 \mathrm{~d}$ depopulation (Table 2) stemming essentially from the $5 \mathrm{~d}_{x z}$ orbital, which was more responsible for the major back-donation to the vacant $\pi^{*}$ orbitals of the neighboring ligands, displaying a loss of $0.82 \mathrm{e}$ and $0.84 \mathrm{e}$ in 1 and 2, respectively, leading to a significant positive atomic charge of +0.662 and 0.728 (BP86-D). Furthermore, the Wiberg bond indices (WBI) gathered in Table 2 provide an in-depth look 
Table 2 Selected parameters obtained for complexes 1 and 2 in their singlet state. Bond distances are given in ( $(\AA)$ and HOMO-LUMO gaps in (eV)

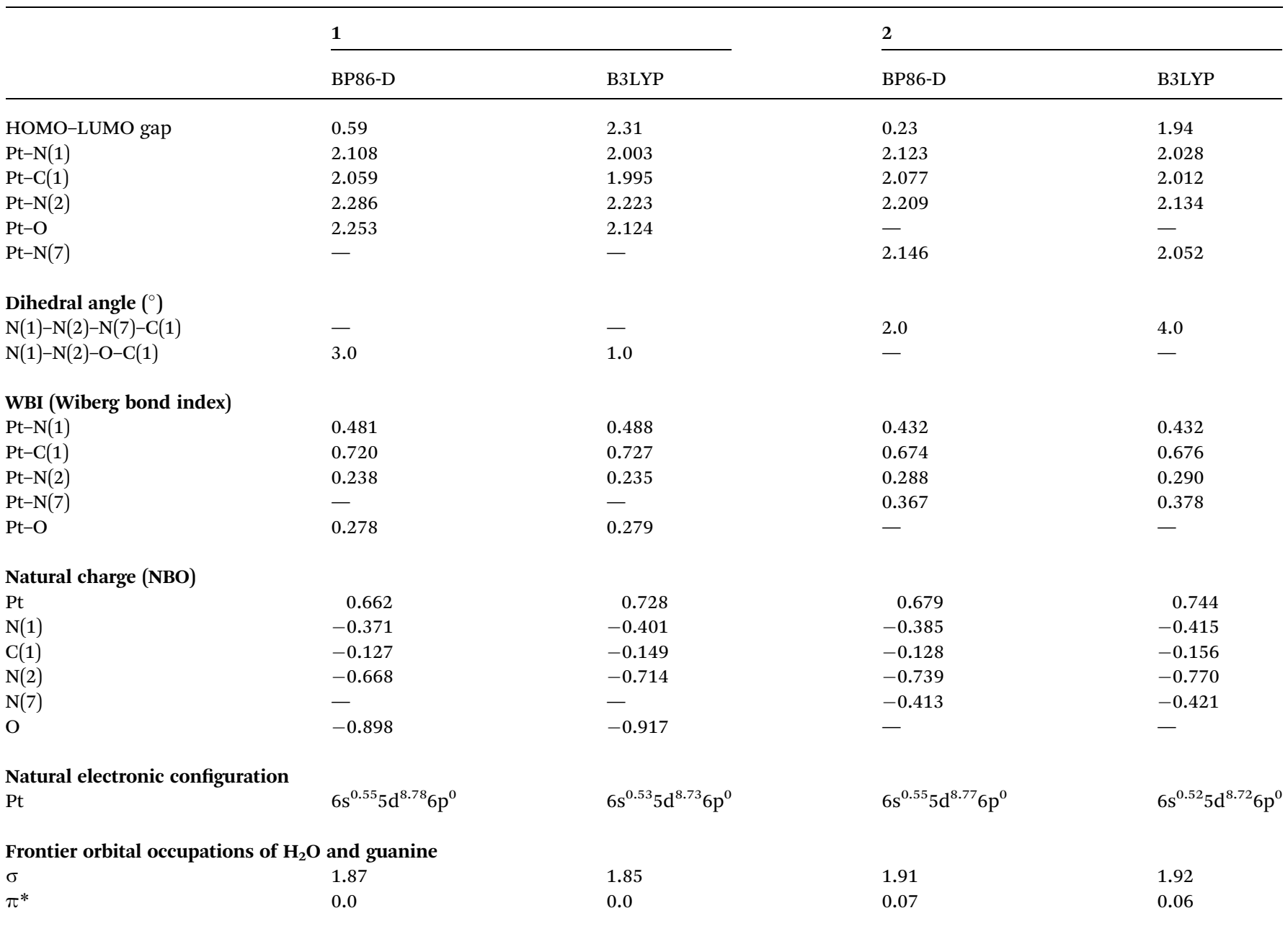

into the bonding between the $\mathrm{Pt}(\mathrm{II})$ center and its surrounding atoms. Indeed, the large $\mathrm{Pt}-\mathrm{C}(1) \mathrm{WBI}$ values of 0.720 and 0.674 (BP86-D) or 0.727 and 0.676 (B3LYP) for 1 and 2, respectively, correspond to double bonding, while the different WBI of Pt-N values of 0.481 and 0.488 (BP86-D) or 0.432 and 0.432 (B3LYP) for 1 and 2, respectively, are comparable describing a dative $\sigma$ bonding. The Pt-O WBI of 0.278 (BP86-D) or 0.279 (B3LYP) also describe a dative $\sigma$-bond between the oxygen lone pair and they are somewhat weaker than those between the Pt center and the different nitrogen atoms.

3.7.3. Energy decomposition analysis. The energy decomposition scheme based on the supermolecular method proposed by Kitaura-Morokuma ${ }^{86,87}$ and developed by Ziegler-Rauk ${ }^{88}$ can be performed easily and now it is conventionally referred to as energy decomposition analysis (EDA). This method has turned out to be extremely useful for treating noncovalent interactions. In this scheme, the total interaction energy $\Delta E_{\text {int }}$ was decomposed into a number of physically meaningful components (without the dispersion term eqn (1) for B3LYP and including the dispersion term eqn (2) for BP86-D):

$$
\Delta E_{\text {int }}=\Delta E_{\text {pauli }}+\Delta E_{\text {elstat }}+\Delta E_{\text {orb }}
$$

$$
\Delta E_{\text {int }}=\Delta E_{\text {pauli }}+\Delta E_{\text {elstat }}+\Delta E_{\text {orb }}+\Delta E_{\text {disp }}
$$

Here, $\Delta E_{\text {elstat }}$ gives the electrostatic interaction energy between the fragments calculated with the electron density distribution in the complex. $\Delta E_{\text {pauli }}$ denotes the repulsive interactions between the fragments, which are caused by the fact that two electrons with the same spin cannot occupy the same region in space. $\Delta E_{\text {orb }}$ accounts for the stabilizing orbital interaction energy as a result of the inter-atomic orbital overlapping. $\Delta E_{\text {disp }}$ measures the dispersion energy of intra-molecular interaction. An essential advantage of the EDA method is that it provides a complete energy description of a complex, not only the intermolecular interactions but also the intramolecular interactions. Therefore, we qualified EDA to be a good and promising method for the data collection and analysis.

The bonding was stronger in the guanine case than in the water one. Hence, the energy decomposition analysis showed an important interaction energy amount of 52.1 (BP86-D) or $45.9 \mathrm{kcal} \mathrm{mol}^{-1}$ (B3LYP) for Pt-N(7) (guanine) compared to that for $\mathrm{Pt}-\mathrm{O}\left(\mathrm{H}_{2} \mathrm{O}\right)$ of 38.5 (BP86-D) or $37.8 \mathrm{kcal} \mathrm{mol}^{-1}$ (B3LYP) (Table 3). 

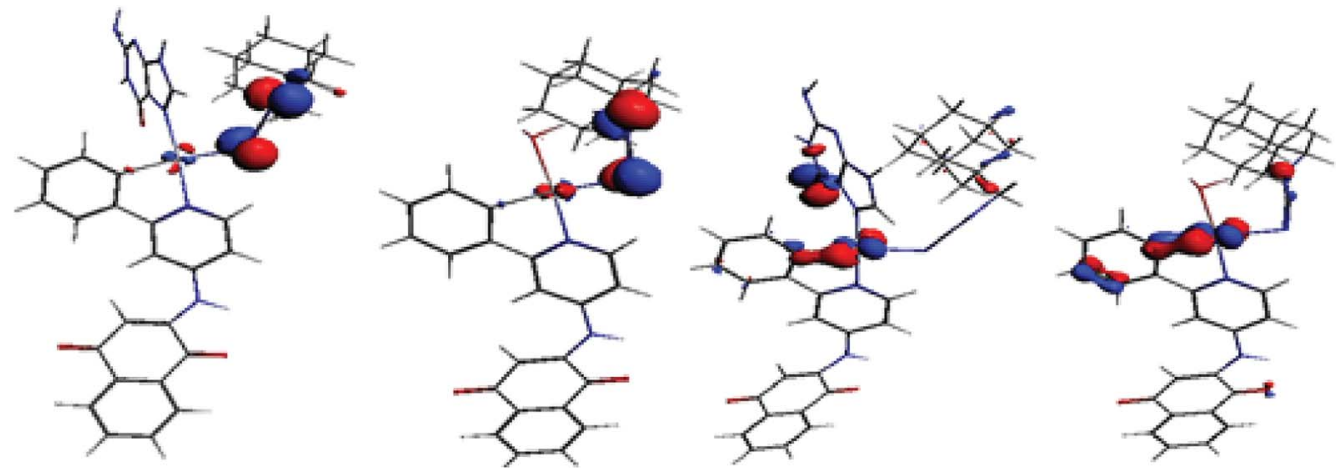

HOMO(Guanine) HOMO $\left(\mathrm{H}_{2} \mathrm{O}\right) \mathrm{HOMO}-3$ (Guanine) HOMO-3 $\left(\mathrm{H}_{2} \mathrm{O}\right)$
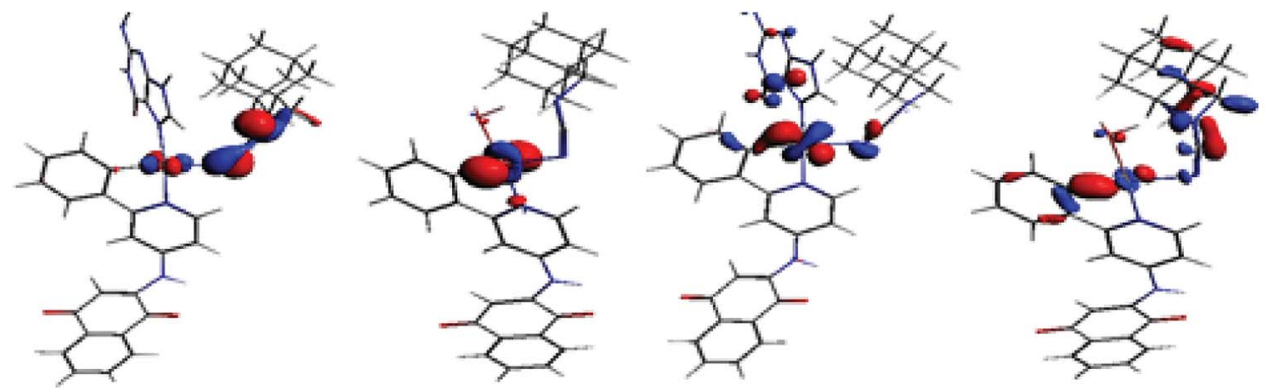

HOMO-1(Guanine)

HOMO-1 $\left(\mathrm{H}_{2} \mathrm{O}\right)$ HOMO-4 (Guanine)

$\mathrm{HOMO}-4\left(\mathrm{H}_{2} \mathrm{O}\right)$
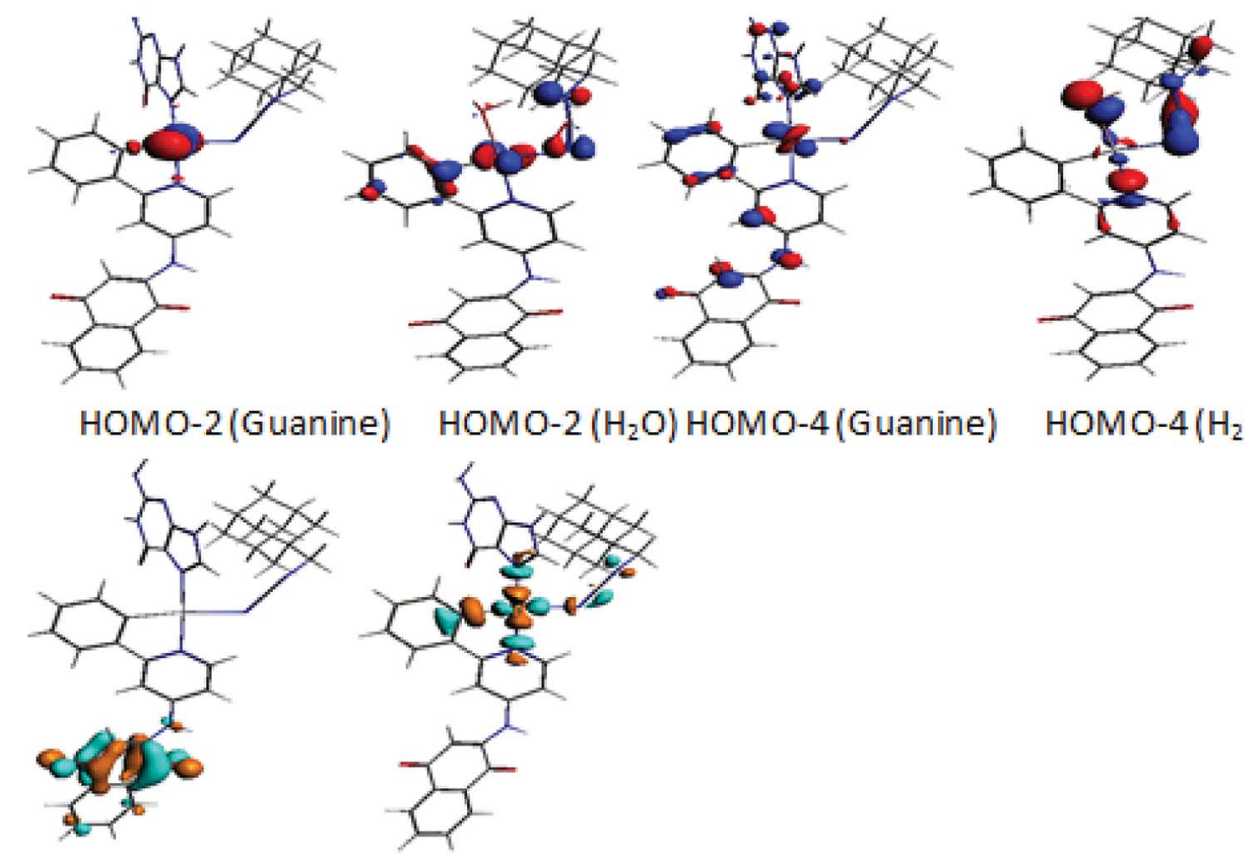

$\mathrm{HOMO}-2\left(\mathrm{H}_{2} \mathrm{O}\right) \mathrm{HOMO}-4$ (Guanine)

$\mathrm{HOMO}-4\left(\mathrm{H}_{2} \mathrm{O}\right)$

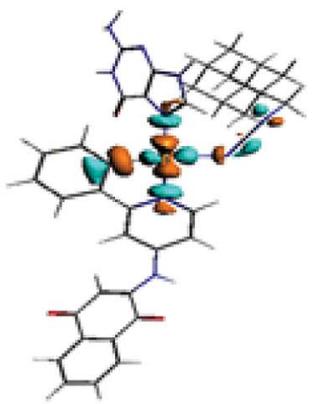

LUMO(Guanine) LUMO+4(Guanine)

Fig. $5 \mathrm{MO}$ plots showing the localizations on Pt and different ligands for complexes 1 and 2 .

Table 4 shows that the values of $\Delta E_{\text {elstat }}$ were more important than those of $\Delta E_{\text {orb }}$ in both the water and guanine cases, where the $\Delta E_{\text {elstat }}$ corresponds to two-thirds of the stabilization contributions to the attractive interaction energy $\left(\Delta E_{\text {elstat }}\right.$ $\left.+\Delta E_{\text {orb }}\right)$.
The interactions within the complex 2 were governed by one-third covalent (32\% BP86-D or 33\% B3LYP) and twothirds electrostatic characters (68\% BP86-D or 67\% B3LYP), giving rise to a more pronounced ionic character than covalent one; while for the water case, the covalent character 
Table 3 Energy decomposition in (eV) obtained by BP86-D and B3LYP. Values between parentheses are in $\mathrm{kcal} \mathrm{mol}^{-1}$

Energy decomposition

\begin{tabular}{llllll} 
& $\Delta E_{\text {int }}$ & $\Delta E_{\text {pauli }}$ & $\Delta E_{\text {elec }}$ & $\Delta E_{\text {orb }}$ & $\Delta E_{\text {disp }}$ \\
\hline Complex 1 & & & & & \\
BP86-D & $-1.67(-38.5)$ & 3.73 & -2.93 & -2.09 & -0.38 \\
B3LYP & $-1.64(-37.8)$ & 3.81 & -3.41 & -2.10 & - \\
& & & & & \\
Complex 2 & & & & & \\
BP86-D & $-2.26(-52.1)$ & 4.89 & -4.13 & -1.94 & -1.08 \\
B3LYP & $-1.99(-45.9)$ & 5.20 & -4.86 & -2.39 & - \\
& & & & & \\
\hline
\end{tabular}

Table 4 Topological parameters in atomic units (a.u.) of electron density $\rho(r)$ and the Laplacian of the electron density $\nabla^{2} \rho(r)$ at the bond critical points $(B C P)$

\begin{tabular}{|c|c|c|c|c|c|c|c|c|}
\hline & \multicolumn{4}{|l|}{1} & \multicolumn{4}{|l|}{2} \\
\hline & \multicolumn{2}{|c|}{ BP86-D } & \multicolumn{2}{|c|}{ B3LYP } & \multicolumn{2}{|c|}{ BP86-D } & \multicolumn{2}{|c|}{ B3LYP } \\
\hline & $\rho(\mathrm{r})$ & $\nabla^{2} \rho(r)$ & $\rho(r)$ & $\nabla^{2} \rho(r)$ & $\rho(r)$ & $\nabla^{2} \rho(r)$ & $\rho(r)$ & $\nabla^{2} \rho(r)$ \\
\hline $\mathrm{Pt}-\mathrm{N}(1)$ & 0.103 & 0.015 & 0.131 & 0.037 & 0.099 & 0.014 & 0.098 & 0.015 \\
\hline $\mathrm{Pt}-\mathrm{C}(1)$ & 0.129 & 0.004 & 0.146 & 0.007 & 0.125 & 0.004 & 0.125 & 0.005 \\
\hline $\mathrm{Pt}-\mathrm{N}(2)$ & 0.066 & 0.004 & 0.076 & 0.007 & 0.078 & 0.007 & 0.077 & 0.007 \\
\hline Pt-N(7) & - & - & - & - & 0.091 & 0.013 & 0.089 & 0.013 \\
\hline $\mathrm{Pt}-\mathrm{O}$ & 0.065 & 0.006 & 0.084 & 0.016 & - & - & - & - \\
\hline
\end{tabular}

increase depends on the ionic one. Indeed for complexes 1 and 2 , the ionic character makes a greater contribution than the covalent character in the stabilization contributions to the attractive interaction energy $\left(\Delta E_{\text {elstat }}+\Delta E_{\text {orb }}\right)$.

The variation of the ionic character is correlated to the NAO charges calculated for the anionic fragment gathered in Table 2, which shows the progressive enhancement of the positive charges of the $\mathrm{Pt}(\mathrm{II})$ center of +0.662 (BP86) or +0.728 (B3LYP) (water) and of +0.679 (BP86) or +0.744 (B3LYP) for (guanine), in agreement with the strengthening of the $\Delta E_{\text {elstat }}$ electrostatic contribution according to the following order: $\mathrm{H}_{2} \mathrm{O}<$ guanine (Table 3).

Furthermore, the donor-acceptor strength of the different ligands were classified according with their relative amounts of $\sigma$-donation and $\pi$-backdonation occurring between the ligand $\mathrm{L}$ and the residual fragment, where the decreasing orders of $\sigma$ donation and $\pi$-backdonation were established as follows, respectively: $\mathrm{H}_{2} \mathrm{O}$ > guanine. With respect to the electronic transfers, the $\mathrm{H}_{2} \mathrm{O}$ ligand can be considered as the strongest $\sigma$ donor.

The $\mathrm{H}_{2} \mathrm{O}$ is only an $\sigma$-donor with an $\sigma$-donation amount of 0.13 (BP86-D), and is considered as a relatively strong $\sigma$-donor compared to the guanine amount of 0.09 (BP96-D). The guanine ligand was revealed to be an $\sigma$-donor rather than a $\pi$-acceptor $(0.07)$ with BP86-D, in agreement with its interaction with metal fragments (Table 3 ). For the guanine case, the $\pi$-acceptor character was more important than the $\sigma$ one, in agreement with the $\sigma$-donation and $\pi$-accepting amounts.
3.7.4. QTAIM calculations. The electronic density analysis using Bader's quantum theory of atoms in molecules (QTAIM) ${ }^{89}$ as implemented in ADF2017, ${ }^{55}$ was used in order to characterize the chemical bonds between atoms in the molecules. ${ }^{90}$

The values of the charge density $\rho(r)$ distribution and the corresponding Laplacian $\nabla^{2} \rho(r)$ at the bond critical point (BCP) allowed this characterization as defined in the literature, ${ }^{89,91,92}$ and provided information about the bonding schemes, as illustrated in Scheme 1. It is clear from the results on model systems that QTAIM is a very useful tool to characterize the nature of bonding. Both BP86 and B3LYP gave comparable values of $\rho(r)$ and $\nabla^{2} \rho(r)$ as illustrated in Table 4 . These values were indicative of an intermediate chemical bonding between the ionic and covalent characters, confirming the same trend obtained within the energy decomposition.

\section{Conclusions}

A new platinum(II) complex cis-Pt(1,4-NQ)(1-ADpcyd)( $\left.\mathrm{H}_{2} \mathrm{O}\right)$, (1ADpcydH: 1-Adamantanemethylcyanamide, 1,4-NQ: 2-[amino(2phenylpyridine)]-1,4-naphthoquinone), was synthesized and characterized. Structural characterization by FT-IR, elemental analyses, multinuclear NMR $\left({ }^{1} \mathrm{H},{ }^{13} \mathrm{C}\right.$, and $\left.{ }^{195} \mathrm{Pt}\right)$, and mass spectrometry showed that the ligands $1-\mathrm{ADpcydH}, 1,4-\mathrm{NQ}$, and one $\mathrm{H}_{2} \mathrm{O}$ molecules were coordinated to the $\mathrm{Pt}(\mathrm{II})$ center in a cisarranged form around the $\mathrm{Pt}(\mathrm{II})$ center. Interaction of the cis-Pt(II) complex 1 with guanine was followed by ${ }^{195} \mathrm{Pt}$ NMR spectroscopy and the final product, cis-Pt(1,4-NQ)(1-ADpcyd)(G), was confirmed by its mass spectrum. Both ${ }^{195} \mathrm{Pt}$ NMR and the mass spectrum confirmed the binding of the $\mathrm{Pt}$ (II) complex 1 to the N7 guanine. The free ligands 1-ADpcydH and 1,4-NQ and complex 1 on MCF-7, HepG-2, and HT-29 cancer cell lines were tested. Here, complex 1 was more active than free ligands and cisplatin in the three cancer cell lines. The lowest $\mathrm{IC}_{50}$ value for complex $\mathbf{1}$ against HT-29 was a 4.5-fold increase compared with cisplatin. Complex 1 showed a higher level of bonding to the DNA in HT-29 cell compared to cisplatin. Both DNA platination and interaction with guanine suggested the importance of the direct attack of nucleotides on cis-Pt(II) complex $\mathbf{1}$ in the mechanism of action for the Pt(II) complex. DFT calculations showed that both complexes 1 and 2, cis-Pt(1,4-NQ)(1-ADpcyd)(L) $\left(\mathrm{L}=\mathrm{H}_{2} \mathrm{O}\right.$ (1), guanine (2)), adopted a square planar geometry, in agreement with the 16-MVE configuration of the $\mathrm{Pt}$ (II) cation. The decomposition energy analysis revealed an important interaction energy amount for Pt$\mathrm{N}(7)$ (guanine) compared to that for $\mathrm{Pt}-\mathrm{O}\left(\mathrm{H}_{2} \mathrm{O}\right)$. For both complexes $\mathbf{1}$ and 2, the electrostatic interactions were more important than those stemming from the orbital ones due to the polarity between the $\mathrm{Pt}(\mathrm{II})$ positive charge and its surrounding atoms negative charge. The present experimental and computational studies may hopefully contribute an important effort toward the development of DNA-targeted Pt(II) metallodrugs.

\section{Author contributions}

The manuscript was written through contributions of all authors. All authors have given approval to the final version of the manuscript. 


\section{Conflicts of interest}

The authors declare no competing financial interest.

\section{Abbreviations}

$\begin{array}{ll}\text { 1,4-NQ } & \text { 2-[Amino(2-phenylpyridine)]-1,4-naphthoquinone } \\ \text { 1-ADpcydH } & \text { 1-Adamantanemethylcyanamide } \\ \text { G } & \text { Guanine } \\ \text { DMSO } & \text { Dimethyl sulfoxide } \\ \text { MeOH } & \text { Methanol } \\ \text { THF } & \text { Tetrahydrofuran } \\ \text { NMR } & \text { Nuclear magnetic resonance } \\ \text { FT-IR } & \text { Fourier-transform infrared } \\ \text { MVE } & \text { Metal valence electrons } \\ \text { ADF } & \text { Amsterdam Density Functional } \\ \text { DFT } & \text { Density functional theory } \\ \text { STO } & \text { Slater-type orbital } \\ \text { ZORA } & \text { Zero-order regular approximation } \\ \text { LDA } & \text { Local density approximation } \\ \text { NAO } & \text { Natural atomic orbital } \\ \text { HOMO } & \text { Highest occupied molecular orbital } \\ \text { LUMO } & \text { Lowest unoccupied molecular orbital } \\ \text { NBO } & \text { Natural bond orbital } \\ \text { EDA } & \text { Energy decomposition analysis } \\ \text { QTAIM } & \text { Quantum theory of atoms in molecules } \\ \text { BCP } & \text { Bond critical point }\end{array}$

\section{Acknowledgements}

The authors acknowledge general support from the School of Chemistry, National University of Ireland (NUI), Galway. BZ is grateful to the Algerian MESRS (Ministère de l'Enseignement Supérieur et de la Recherche Scientifique) and DGRSDT (Direction Générale de la Recherche Scientifique et du Développement Technologique) for Financial support.

\section{References}

1 R. Cortés, M. Crespo, L. Davin, R. Martín, J. Quirante, D. Ruiz, R. Messeguer, C. Calvis, L. Baldomà, J. Badia, et al., Eur. J. Med. Chem., 2012, 54, 557-566.

2 P. Chellan, K. M. Land, A. Shokar, A. Au, S. H. An, C. M. Clavel, P. J. Dyson, C. de Kock, P. J. Smith, K. Chibale, et al., Organometallics, 2012, 31, 5791-5799.

3 J. Quirante, D. Ruiz, A. González, C. López, M. Cascante, R. Cortés, R. Messeguer, C. Calvis, L. Baldomà, A. Pascual, et al., J. Inorg. Biochem., 2011, 105, 1720-1728.

4 J. Ruiz, V. Rodríguez, N. Cutillas, A. Espinosa and M. J. Hannon, J. Inorg. Biochem., 2011, 105, 525-531.

5 J. Ruiz, C. Vicente, C. de Haro and A. Espinosa, Inorg. Chem., 2011, 50, 2151-2158.

6 P. Wang, C.-H. Leung, D.-L. Ma, R. W.-Y. Sun, S.-C. Yan, Q.-S. Chen and C.-M. Che, Angew. Chem., Int. Ed., 2011, 50, 2554-2558.
7 H. Samouei, M. Rashidi and F. W. A. Heinemann, J. Organomet. Chem., 2011, 696, 3764-3771.

8 J. Albert, R. Bosque, M. Crespo, J. Granell, C. López, R. Cortés, A. González, J. Quirante, C. Calvis, R. Messeguer, et al., Bioorg. Med. Chem., 2013, 21, 4210-4217.

9 M. Crespo, Inorganics, 2014, 2, 115-131.

10 N. Farrell, in Platinum-based Drugs in Cancer Therapy, ed. L. R. Kelland and N. P. Farrell, Humana Press, Totowa, NJ, 2000, pp. 321-338.

11 E. R. Jamieson and S. J. Lippard, Chem. Rev., 1999, 99, 24672498.

12 N. J. Wheate, B. J. Evison, A. J. Herlt, D. R. Phillips and J. G. Collins, Dalton Trans., 2003, 3486-3492.

13 N. Farrell, Y. Qu, L. Feng and B. Van Houten, Biochemistry, 1990, 29, 9522-9531.

14 N. Farrell, Y. Qu and P. Hacker, J. Med. Chem., 1990, 33, 2179-2184.

15 J. D. Roberts, B. van Houten, Y. Qu and N. P. Farrell, Nucleic Acids Res., 1989, 17, 9719-9733.

16 Z. D. Bugarcic, T. Soldatovic, R. Jelic, B. Alguero and A. Grandas, Dalton Trans., 2004, 3869-3877.

17 U. Frey, J. D. Ranford and P. J. Sadler, Inorg. Chem., 1993, 32, 1333-1340.

18 A. Gelasco and S. J. Lippard, Anticancer activity of cisplatin and related complexes, in Metallopharmaceuticals I. Topics in Biological and Inorganic Chemistry, ed. M. J. Clarke and P. J. Sadler, Springer-Verlag, Berlin, 1999, vol. 1, pp. 1-43.

19 J. Reedijk, Chem. Rev., 1999, 99, 2499-2510.

20 (a) K. J. Barnham, Z. J. Guo and P. J. Sadler, J. Chem. Soc., Dalton Trans., 1996, 2867-2876; (b) K. J. Barnham, M. I. Djuran, P. D. Murdoch and P. J. Sadler, J. Chem. Soc., Chem. Commun., 1994, 721-722; (c) K. J. Barnham, M. I. Djuran, P. D. Murdoch, J. D. Ranford and P. J. Sadler, J. Chem. Soc., Dalton Trans., 1995, 3721-3726; (d) J. M. Teuben and J. Reedijk, J. Biol. Inorg Chem., 2000, 5, 463-468.

21 H.-C. Tai, R. Brodbeck, J. Kasparkova, N. J. Farrer, V. Brabec, P. J. Sadler and R. J. Deeth, Inorg. Chem., 2012, 51, 68306841.

22 F. Sebesta and J. V. Burda, J. Inorg. Biochem., 2017, 172, 100109.

23 E. N. da Silva Jr, R. F. S. Menna-Barreto, M. C. F. R. Pinto, R. S. F. Silva, D. V. Teixeira, M. C. B. V. de Souza, C. A. de Simone, S. L. de Castro, V. F. Ferreira and A. V. Pinto, Eur. J. Med. Chem., 2008, 43, 1774-1780.

24 S. L. Castro, F. S. Emery and E. N. da Silva Jr, Eur. J. Med. Chem., 2013, 69, 678-700.

25 G. A. M. Jardim, W. J. Reis, M. F. Ribeiro, F. M. Ottoni, R. J. Alves, T. L. Silva, M. O. F. Goulart, A. L. Braga, R. F. S. Menna-Barreto, K. Salomão, S. L. Castro and E. N. da Silva Jr, RSC Adv., 2015, 5, 78047-78060.

26 (a) L. Lin, Q. Shen, G.-R. Chen and J. Xie, Bioorg. Med. Chem., 2008, 16, 9757; (b) B. D. Bala, S. Muthusaravanan, T. S. Choon, M. A. Ali and S. Perumal, Eur. J. Med. Chem., 2014, 85, 737-746.

27 W. S. Nascimento, C. A. Camara and R. N. de Oliveira, Synthesis, 2011, 20, 3220-3224. 
28 A. P. Neves, M. X. G. Pereira, E. J. Peterson, R. Kipping, M. D. Vargas, F. P. Silva Jr, J. W. M. Carneiro and N. P. Farrell, J. Inorg. Biochem., 2013, 119, 54-64.

29 M. Chinnapattu, K. I. Sathiyanarayanan and P. S. Iyer, Bioorg. Med. Chem. Lett., 2015, 25, 952-955.

30 L. Wanka, K. Iqbal and P. R. Schreiner, Chem. Rev., 2013, 113, 3516-3604.

31 S. Y. Sun, P. Yue, W. K. Hong and R. Lotan, Cancer Res., 2000, 60, 7149-7155.

32 M. Horvat, L. Uzelac, M. Marjanovic, N. Cindro, O. Frankovic, K. Mlinaric-Majerski, M. Kralj and N. Basaric, Evaluation of Antiproliferative Effect of N-(alkyladamantyl)phthalimides In vitro, Chem. Biol. Drug Des., 2012, 79, 497-506.

33 J. D. Parkes, R. C. Baxter, C. D. Marsden and J. E. Rees, J. Neurol., Neurosurg. Psychiatry, 1974, 37, 422-426.

34 J. Beigel and M. Bray, Antiviral Res., 2008, 78, 91-102.

35 A. Garcia, R. C. Machado, R. M. Grazul, M. T. P. Lopes, C. C. Corrêa, H. F. Dos Santos, M. V. de Almeida and H. Silva, J. Biol. Inorg Chem., 2016, 21, 275-292.

36 L. Tabrizi and H. Chiniforoshan, RSC Adv., 2017, 7, 3416034169.

37 L. Tabrizi and H. Chiniforoshan, Dalton Trans., 2017, 46, 2339-2349.

38 L. Tabrizi and H. Chiniforoshan, Dalton Trans., 2016, 45, 18333-18345.

39 L. Tabrizi and H. Chiniforoshan, BioMetals, 2017, 30, 59-70.

40 L. Tabrizi and H. Chiniforoshan, Invest. New Drugs, 2016, 34, 723-732.

41 L. Tabrizi, P. McArdle, A. Erxleben and H. Chiniforoshan, Inorg. Chim. Acta, 2015, 438, 94-104.

42 M. Jazestani, H. Chiniforoshan, L. Tabrizi and P. McArdle, J. Biomol. Struct. Dyn., 2017, 35, 2055-2065.

43 M. Jazestani, H. Chiniforoshan, L. Tabrizi, P. McArdle and B. Notash, Inorg. Chim. Acta, 2016, 450, 402-410.

44 A. Zaiter and B. Zouchoune, Struct. Chem., 2018, 29, 13071320.

45 N. Naili and B. Zouchoune, Struct. Chem., 2018, 29, 725-739.

46 B. Zouchoune, S. M. Zendaoui and J. Y. Saillard, J. Organomet. Chem., 2018, 858, 47-52.

47 A. Saiad and B. Zouchoune, Can. J. Chem., 2015, 93, 10961108.

48 N. Benhamada, R. Bouchene, S. Bouacida and B. Zouchoune, Polyhedron, 2015, 91, 59-67.

49 S. Drideh, B. Zouchoune, S.-M. Zendaoui and J.-Y. Saillard, Theor. Chem. Acc., 2018, 137, 99.

50 F. Chekkal, S. M. Zendaoui, B. Zouchoune and J. Y. Saillard, New J. Chem., 2013, 37, 2293-2302.

51 A. Benmachiche, S. M. Zendaoui, S. E. Bouaoud and B. Zouchoune, Int. J. Quantum Chem., 2013, 113, 985-996.

52 M. S. Zendaoui, J. Y. Saillard and B. Zouchoune, ChemistrySelect, 2016, 5, 940-948.

53 R. J. Letcher, W. Zhang, C. Bensimon and R. J. Crutchley, Inorg. Chim. Acta, 1993, 210, 183-191.

54 M. C. Alley, D. A. Scudiero, A. Monks, M. L. Hursey, M. J. Czerwinski, D. L. Fine, B. J. Abbott, J. G. Mayo, R. H. Shoemaker and M. R. Boyd, Cancer Res., 1988, 48, 589.
55 ADF2007.01., SCM Theoretical Chemistry, Vrije Universiteit, Amsterdam, The Netherlands, http://www.scm.com.

56 E. J. Baerends, D. E. Ellis and P. Ros, Chem. Phys., 1973, 2, 41-51.

57 G. te Velde and E. J. Baerends, J. Comput. Phys., 1992, 99, 8498.

58 C. Fonseca Guerra, J. G. Snijders, G. te Velde and E. Baerends, Theor. Chem. Acc., 1998, 99, 391-403.

59 F. M. Bickelhaupt and E. Baerends, J. Rev. Comput. Chem., 2000, 15, 1-86.

60 G. te Velde, F. M. Bickelhaupt, E. J. Baerends, C. F. Guerra, S. J. A. van Gisbergen, J. G. Snijders and T. Ziegler, J. Comput. Chem., 2001, 22, 931-967.

61 S. D. Vosko, L. Wilk and M. Nusair, Can. J. Phys., 1980, 58, 1200-1211.

62 S. Grimme, J. Comput. Chem., 2006, 27, 1787-1799.

63 A. D. Becke, J. Chem. Phys., 1986, 84, 4524-4529.

64 A. D. Becke, Phys. Rev. A, 1988, 38, 3098.

65 J. P. Perdew, Phys. Rev. B: Condens. Matter Mater. Phys., 1986, 33, 8822-8824.

66 J. P. Perdew, Phys. Rev. B: Condens. Matter Mater. Phys., 1986, 34, 7406.

67 A. D. Becke, J. Chem. Phys., 1993, 98, 5642-5648.

68 C. Lee, W. Yang and R. G. Parr, Phys. Rev. B: Condens. Matter Mater. Phys., 1988, 37, 785-789.

69 L. Versluis and T. Ziegler, J. Chem. Phys., 1988, 88, 322.

70 L. Fan and T. Ziegler, J. Chem. Phys., 1992, 96, 9005-9012.

71 L. Fan and T. Ziegler, J. Phys. Chem., 1992, 96, 6937-6941.

72 P. Flükiger, H. P. Lüthi, S. Portmann and J. Weber, MOLEKEL, Version 4.3.win32, Swiss Center for Scientific Computing (CSCS), Switzerland, 2000-2001, http:// www.cscs.ch/molekel/.

73 K. B. Wiberg, Tetrahedron, 1968, 24, 1083-1084.

74 F. Weinhold and C. R. Landis, Valency and Bonding: A Natural Bond Orbital Donor-Acceptor Perspective, Cambridge University Press, Cambridge, UK, 2005.

75 E. D. Glendening, J. K. Badenhoop, A. E. Reed, J. E. Carpenter, J. A. Bohmann, C. M. Morales and F. Weinhold, Natural Bond Orbitals "Analysis Programs", Theoretical Chemistry Institute, University of Wisconsin, Madison, WI, 2001.

76 S. Chandra and Vandana, Spectrochim. Acta, Part A., 2014, 129, 333-338.

77 V. Mishra and N. Thirupathi, ACS Omega, 2018, 3, 60756090.

78 G. Arena, L. M. Scolaro, R. F. Pasternack and R. Romeo, Inorg. Chem., 1995, 34, 2994-3002.

79 Q.-P. Qin, Z.-F. Chen, J.-L. Qin, X.-J. He, Y.-L. Li, Y.-C. Liu, K.-B. Huang and H. Liang, Eur. J. Med. Chem., 2015, 92, 302-313.

80 D. Michalska and R. Wysokiński, Collect. Czech. Chem. Commun., 2004, 69, 63-72.

81 J. V. Burda, J. Šponer and J. Leszczynski, JBIC, J. Biol. Inorg. Chem., 2000, 5, 178-188.

82 X.-P. Zhang, V. Y. Chang, J. Liu, X.-L. Yang, W. Huang, Y. Li, C.-H. Li, G. Muller and X.-Z. You, Inorg. Chem., 2014, 54, 143152. 
83 J. Li, F. Liang, Y. Zhao, X. Liu, J. Fan and L. Liao, J. Mater. Chem. C, 2017, 5, 6202-6209.

84 S. Yao, J. P. Plastaras and L. G. Marzilli, Inorg. Chem., 1994, 33, 6061-6077.

85 P. W. Asman, J. Coord. Chem., 2017, 1-20.

86 K. Kitaura and K. Morokuma, Int. J. Quantum Chem., 1976, 10, 325 .

87 K. Morokuma, Acc. Chem. Res., 1977, 10, 294-300.
88 T. Ziegler and A. Rauk, Theor. Chem. Acc., 1977, 46, 1-10. 89 R. F. W. Bader, Atoms in Molecules a Quantum Theory, Clanderon Press, Oxford, UK, 1990.

90 R. F. W. Bader, J. Phys. Chem. A, 1998, 102, 7314-7323.

91 P. L. A. Popelier and G. Logothetis, J. Organomet. Chem., 1998, 555, 101-111.

92 T. S. Thakur and G. R. Desiraju, J. Mol. Struct.: THEOCHEM, 2007, 810, 143-154. 